\title{
Isolation, growth and identification of colony-forming cells with erythroid, myeloid, dendritic cell and NK-cell potential from human fetal liver
}

\author{
Marcus O. Muench ${ }^{1 *}$, David L. Suskind ${ }^{1}$ and Alicia Bárcena ${ }^{1}$ \\ ${ }^{1}$ Department of Laboratory Medicine, University of California at San Francisco. 3rd \& Parnassus Ave., Room U-440; San \\ Francisco, CA 94143-0793. . Phone: (415) 476-8420 Fax: (415) 476-2956 Email: muench@itsa.ucsf.edu. \\ * To whom correspondence should be addressed.
}

Submitted: April 16, 2002; Accepted: May 27, 2002; Published: June 11, 2002.

Indexing terms: fetal tissue; hematopoietic stem cells; cell differentiation; natural killer cells; dendritic cells.

\begin{abstract}
The study of hematopoietic stem cells (HSCs) and the process by which they differentiate into committed progenitors has been hampered by the lack of in vitro clonal assays that can support erythroid, myeloid and lymphoid differentiation. We describe a method for the isolation from human fetal liver of highly purified candidate HSCs and progenitors based on the phenotypes $\mathrm{CD} 38^{-} \mathrm{CD} 34^{++}$and $\mathrm{CD} 38^{+} \mathrm{CD} 34^{++}$, respectively. We also describe a method for the growth of colony-forming cells (CFCs) from these cell populations, under defined culture conditions, that supports the differentiation of erythroid, $\mathrm{CD} 14 / \mathrm{CD} 15^{+}$myeloid, $\mathrm{CD} 1 \mathrm{a}^{+}$dendritic cell and $\mathrm{CD} 56^{+} \mathrm{NK}$ cell lineages. Flow cytometric analyses of individual colonies demonstrate that CFCs with erythroid, myeloid and lymphoid potential are distributed among both the $\mathrm{CD} 38^{-}$and $\mathrm{CD} 38^{+}$ populations of $\mathrm{CD} 34^{++}$progenitors.
\end{abstract}

\section{INTRODUCTION}

Maintenance of blood cell homeostasis involves the daily production of a tremendous number of blood cells from a relatively small pool of stem cells. Regulation of hematopoiesis is complex involving both hormonal and local regulatory mechanisms that can promote or inhibit the growth and differentiation of stem cells into progenitors and, in turn, mature blood cells. In adult mammals, hematopoiesis occurs primarily in the bone marrow. However, hematopoiesis can occur in other locations as well such as in the thymus, which is specialized in the generation of $\mathrm{T}$ cells. In addition, small numbers of natural killer (NK) cells, B cells, dendritic cells (DCs) and myeloid cells are also generated in the thymus $(1,2)$. The spleen offers another potential site for hematopoiesis, especially in small animals. Hematopoietic progenitors have also been found in the adult liver (3) .

Hematopoietic progenitors and stem cells are distributed continually to favorable sites of hematopoiesis. This is evidenced by the presence of a small number of these cells that can be found circulating in the peripheral blood (4). The numbers of circulating progenitors and stem cells can increase dramatically when hematopoietic activity is increased. Treatment with various hematopoietic growth factors or recovery from chemotherapeutic injury can result in the mobilization of hematopoietic progenitors and stem cells (5). This is reminiscent of mammalian development, a period of rapid growth in hematopoietic tissues marked by high levels of circulating progenitors and stem cells and a remarkable series of transitions between hematopoietic tissues $(6,7)$. Hematopoiesis begins extraembryonically in the blood islands of the yolk sac (6). Intraembryonic hematopoiesis is first observed in the paraaortic splanchnopleura or aorta-gonadmesonephros region and moves to the liver, the primary site of hematopoiesis during much of fetal life (7). In mice, hematopoiesis transitions from the liver to the spleen in the older fetus, and then to the bone marrow around the time of birth. In humans, the relocation of hematopoiesis from the liver to the bone marrow begins early in the second trimester and the spleen is never a significant location for hematopoiesis (8).

A large number of culture systems have been developed for the study of hematopoiesis in vitro. One such system that has been prominent in much of the research in this field is the colonyforming cell (CFC) or colony-forming unit-culture (CFU-C) assay $(9,10)$. In its basic form, the CFC assay is a clonal assay used for the enumeration of hematopoietic progenitors. Progenitors are suspended in a combination of culture medium,

(C) 2002 Biological Procedures Online. Published in Biological Procedures Online under license from the author(s). Copying, printing, redistribution and storage permitted. 
growth factors and a semi-solid matrix such as methylcellulose or agarose. Over time the suspended progenitors proliferate and differentiate forming a colony of blood cells that can be readily counted using an inverted or dissecting microscope. The CFC assay has evolved since its beginnings in the mid 1960's. Layers of feeder cells, a source of growth factors, were replaced by conditioned media and eventually recombinant cytokines, discovered in part through the use of the CFC assay. There is also no longer a need for serum in the culture medium as various formulations of defined serum components have been devised that can substitute serum $(11,12)$.

Stem cells are defined by their extensive proliferative capacity, including a limited ability for self-renewal, and their pluripotentiality. Although no CFC assay has ever been developed that can definitively detect stem cells, CFC assays have been developed to measure the properties of extensive proliferative capacity and pluripotentiality. High-proliferative potential CFCs (HPP-CFCs) are a primitive subpopulation of progenitors, likely including stem cells, that are characterized by their ability to form large colonies containing $1 \times 10^{4}$ cells (13). HPP-CFCs were first detected when two sources of conditioned media were combined to provide a synergistic combination of cytokines that supported the growth of primitive progenitors, a characteristic requirement of primitive progenitors. The blast cell colony assay, similar to the HPPCFC assay, is another variant of the CFC assay that detects cells with an extensive proliferative capacity based, in part, on their potential to generate secondary colonies when replated (14). The conditions that support the generation of myeloid and erythroid cells from CFCs were developed early in the evolution of the CFC assay. However, growth of lymphoid progenitors and multipotent progenitors with lymphoid potential hasn't been possible until more recently. With the discovery of the cytokines interleukin (IL)-7 and IL-15, the clonal growth of murine B cell progenitors (15-17) and NKcell progenitors (18) was achieved. Indeed, murine multipotent CFCs can form colonies with myeloid, erythroid and lymphoid cells $(19,20)$. Similar successes with human lymphoid and multipotent CFCs have trailed the murine results. Initially, human NK-cell colonies were grown from committed lymphoid CFCs isolated from thymic tissue (21). Recently, our laboratory reported the growth of CFCs with erythroid, myeloid, DC and NK cell potential (22). These CFCs were isolated from human fetal liver tissues, grown and detected by the methods detailed in this report.

\section{MATERIALS AND METHODS}

\section{Human fetal liver progenitors}

Livers were harvested from midgestation fetuses obtained with maternal consent from elective abortions. Research with fetal tissue was performed with approval of the Committee of Human Research at our institute. Two subpopulations of progenitors were isolated by the method detailed in the Protocol section: $\mathrm{CD} 38^{-} \mathrm{CD} 34^{++}$lineage- (lineage or $\mathrm{Lin}=\mathrm{CD} 3$, CD14, CD19, CD20, CD56 and CD235a) and $\mathrm{CD} 8^{+} \mathrm{CD} 34^{++} \mathrm{Lin}^{-}$fetal liver cells (23). For simplicity, these two populations of cells will be referred to as $\mathrm{CD} 38^{-}$and $\mathrm{CD} 38^{+}$progenitors. The $\mathrm{CD}^{-}$population is enriched in hematopoietic stem cells whereas the $\mathrm{CD} 38^{+}$population is an intermediate population of progenitors that still expresses high levels of CD34 and is believed to be derived from the CD38 stem cells $(23,24)$.

\section{Colony-forming cell assay}

A detailed description of the culture conditions used to grow multipotent CFC is given in the Protocol section. Briefly, 50 to 100 cells were plated/culture dish and 3 to 8 dishes were analyzed for each experiment. Progenitors were grown in semisolid medium under serum-deprived conditions supplemented with six recombinant human cytokines: kit ligand (KL), flk2/flt-3 ligand (FL), GM-CSF, thrombopoietin (TPO), erythropoietin (EPO) and interleukin-15 (IL-15). KL, FL, TPO and IL-15 were purchased from R\&D Systems, Inc. (Minneapolis, MN, http://www.rndsystems.com). EPO was purchased from Amgen (Thousand Oaks, CA, http://www.amgen.com and GM-CSF (Leukine) from Immunex Corporation (Seattle, WA, http://www.immunex.com). The serum-deprived medium used has been shown to be superior to serum-replete medium in supporting the growth of myeloid and erythroid cells $(25,26)$. The cytokines used were chosen based on previous experiments that indicated that the combination $\mathrm{KL}+\mathrm{FL}+\mathrm{GM}-$ CSF+IL-15 supports the generation NK cells from CD38 progenitors (27). Furthermore, GM-CSF, FL, KL and IL-15 have also been shown to support the growth of DCs (28-30). EPO and ML were further added to the cultures to support erythroid and megakaryocytic development, which did not appear to interfere with the development of the myeloid, dendritic and NK cells (22). CFCs were cultured for 3 weeks and analyzed for lineage composition.

\section{Analyses of colony lineage composition}

Colonies containing erythrocytes were identified visually by the presence of hemoglobinized cells. The presence of myeloid $\left(\mathrm{CD} 14^{+}\right.$and/or $\mathrm{CD} 15^{+}$cells) and NK cells $\left(\mathrm{CD} 56^{+}\right.$cells) was determined by flow cytometric analyses of live cells isolated from individually plucked colonies. Anti-CD14-PE (clone TüK4) (Caltag Laboratories, Burlingame, CA, http://www.caltag.com), anti-CD15-PE (clone VIMC6) (Caltag Laboratories) and anti-CD56-FITC (clone C5.9) (Exalpha Corporation, Boston, MA, http://www.exalpha.com) were the monoclonal antibodies (mAbs) used to stain the colonies. In some experiments, anti-CD1a-PE (clone T6) (Beckman Coulter, Inc., Miami, FL, http://www.beckmancoulter.com) was used to detect DCs combined with anti-CD14-APC (clone M5E2) (BD Biosciences, http://www.bdbiosciences.com), antiCD15-APC (clone HI98) (BD Biosciences) and anti-CD56FITC. A detailed protocol for the analysis of colony lineage composition is presented in the Protocol section. A FACScan or FACSCalibur flow cytometer (BD Biosciences) was used to analyze the stained colonies. 


\section{RESULTS AND DISCUSSION}

The early stages of lymphoid development are only partially characterized. Most schema depicting hematopoietic differentiation place the separation of lymphoid progenitors from myeloid-erythroid progenitors as the first major branch point in hematopoiesis. This early division of lymphopoiesis from myeloerythropoiesis does have some basis in experimental observation. Galy et al. isolated a $\mathrm{CD} 10^{+} \mathrm{CD} 38^{+}$ committed lymphoid progenitor from among early hematopoietic progenitors that express high levels of CD34 (31). These lymphoid progenitors were capable of generating $T$ cells, B cells, NK cells and DCs. Since there is abundant evidence that stem cells reside among CD $38^{-} \mathrm{CD} 34^{++}$cells (24), a model in which pluripotent $\mathrm{CD} 38^{-}$stem cells differentiate into multipotent $\mathrm{CD} 38^{+}$lymphoid and myeloerythroid progenitors can be envisioned.

To further research the development of lymphoid progenitors, we set out to define in vitro conditions for the clonal growth of progenitors with lymphoid, myeloid and erythroid potential. Two cell populations expressing high levels of CD34 were studied, $\mathrm{CD} 38^{-}$candidate stem cells and $\mathrm{CD} 38^{+}$progenitors. These cells were isolated from human fetal liver according to the criteria depicted in Fig. 1. Cells were isolated based on their lack of staining with PI (Fig. 1A), low side-light scatter (Fig. 1B) and lack of expression of a panel of Lin markers (Fig. 1C). Cells were sorted using regions similar to the ones shown in Fig. 1D. These regions are drawn conservatively since analyses of the sorted cells (Fig. 1E and F) always indicate that the sorted cells have spread beyond the original regions used to sort the cells. Nonetheless, highly purified populations of progenitors and candidate stem cells can be obtained. These cells were cultured under serum-deprived conditions using a methylcellulose-based colony assay system. The cytokine cocktail $\mathrm{KL}+\mathrm{FL}+\mathrm{TPO}+\mathrm{GM}-\mathrm{CSF}+\mathrm{EPO}+\mathrm{IL}-15$ was used, which supported the growth of erythroid, myeloid, NK cells and DCs. Currently, conditions that support the development of human $\mathrm{B}-$ and T-cells in colony assays remain elusive, although B cells have been generated under defined liquid culture conditions (27). We speculate that the efficiency of B-cell formation remains below the threshold for detection of these cells within individual colonies (22).

Colonies grown from the two cell populations were scored using a dissecting microscope. To better insure clonality we have settled on plating only 50 sorted cells/plate and analyzing up to 8 dishes for each cell population. At this starting density we obtained an average 9.5 and 11 colonies/dish for CD38 and $\mathrm{CD} 38^{+}$progenitors, respectively (22). Even at these low densities colonies were sometimes closely spaced or overlapping. However, we have had little difficulty in harvesting these colonies by omitting to harvest portions of the colony that may be contaminated with another colony's cells. Before harvest, the estimated size and the presence or absence of hemoglobinized erythrocytes was recorded as each colony was visualized. Examples of myeloid colonies are shown in Figs. $2 \mathrm{~A}$ and $2 \mathrm{~B}$ and representative myeloerythroid colonies are shown in Figs. 2C-F. After recording the attributes of a colony, the colony was drawn into a $200 \mu 1$ pipette tip (Figs. 2D-F) and dispersed in a solution of blocking buffer and mAbs.
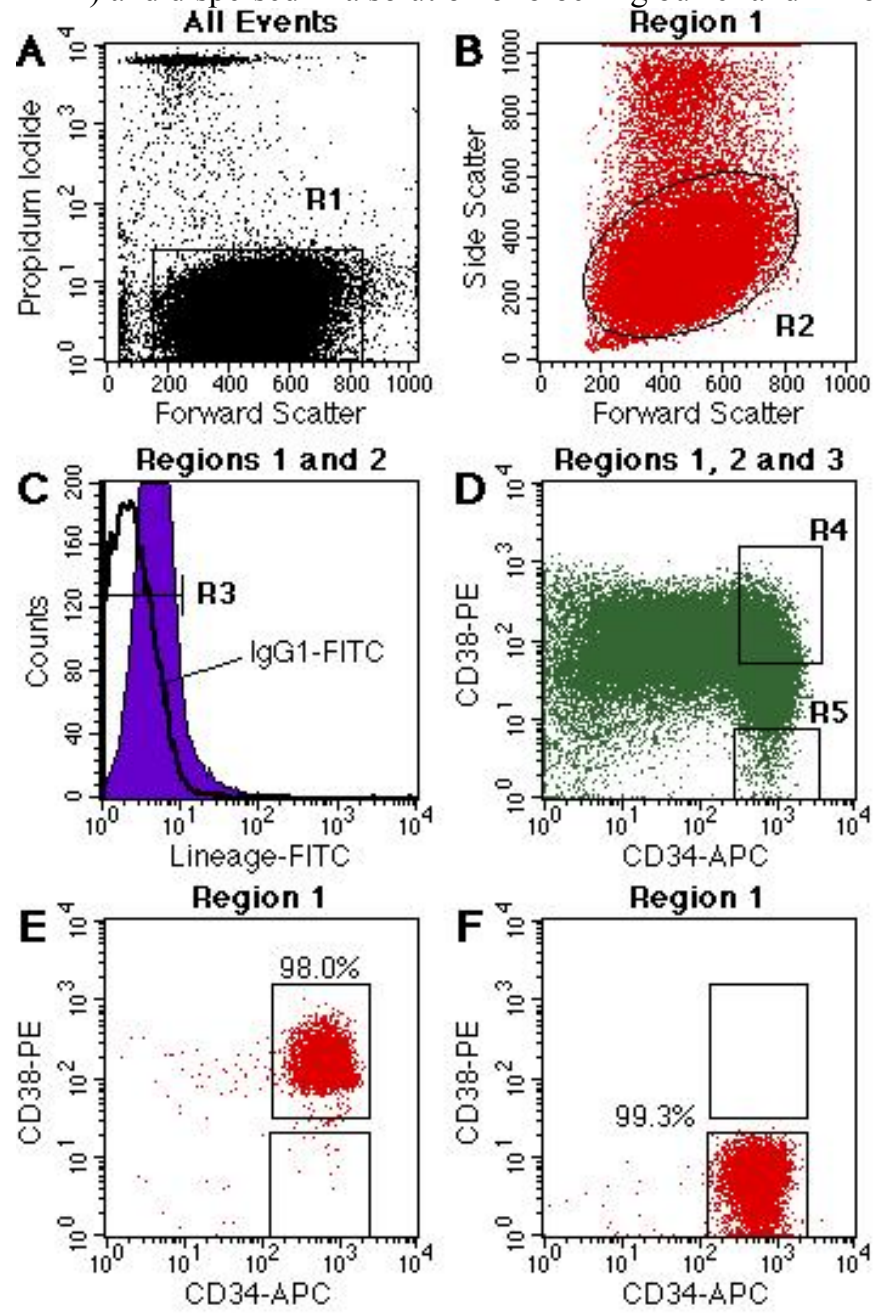

Fig. 1: Isolation of primitive hematopoietic progenitors from human fetal liver. Hematopoietic progenitors were isolated by FACS following enrichment by two rounds of immunomagnetic bead depletion of $\mathrm{Lin}^{+}$cells and isolation of light-density cells. Dead cells and debris are removed using a region (A, R1) drawn to include $\mathrm{PI}^{-}$events with a moderate forward scatter. Cells with a low to medium side scatter are then selected using a second region (B, R2). Any remaining Lin-FITC ${ }^{+}$cells are then removed with a third region (R3) as shown in $\mathrm{C}$. Expression of CD34 and CD38 are then viewed on events gated to fall within regions 1-3 (D). CD $38^{+} \mathrm{CD} 34^{++}$and $\mathrm{CD} 38^{-} \mathrm{CD} 34^{++}$events are selected using regions 4 and 5 , respectively, as indicated. These regions are drawn conservatively as analysis of the sorted cells (E and F) usually indicates some slight spread of the populations outside the sort regions. Ideally, the isolated $\mathrm{CD} 38^{+}$and $\mathrm{CD} 38^{-}$progenitors will be nearly contiguous, but non-overlapping, populations.

After staining, individual colonies were analyzed by flow cytometry (Fig. 3). Live and dead cells were distinguished using PI. Considerable numbers of dead cells and debris were removed from analysis using a gate similar to the one shown in Fig. 1A. As shown in Fig. 3, cell populations were observed

Biological Procedures Online • Vol. 4 No. 1 •June 11, 2002•www.biologicalprocedures.com 
with different light scatter properties (22). Erythrocytes, NK cells and a subpopulation of the CD14 ${ }^{+}$and $\mathrm{CD} 15^{+}$cells had a low side scatter profile (Fig. 3A, blue events). Most cells with a high side scatter had a high autofluorescence and many also expressed CD14 (Fig. 3, red events). These high side scatter cells represent primarily DCs as discussed below.
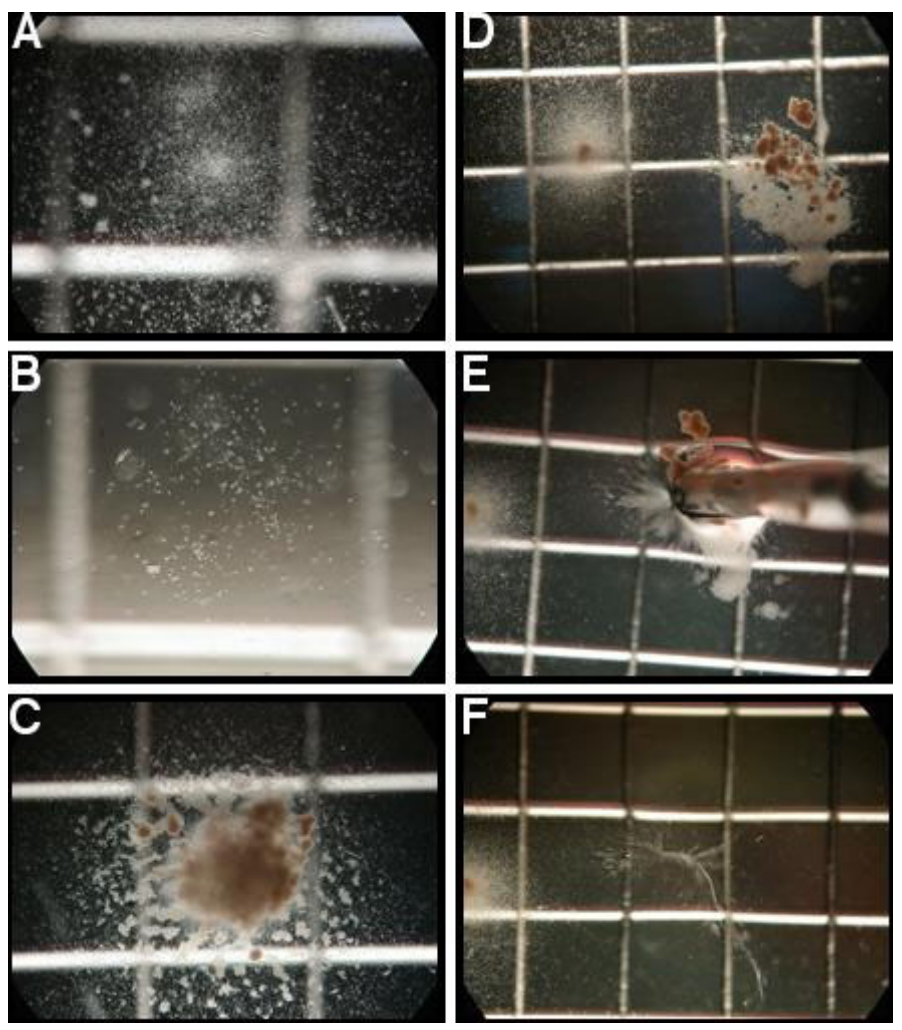

Fig. 2: Colony formation by $\mathrm{CD38}^{-}$progenitors. Examples of myeloid colonies are shown in $\mathrm{A}$ and $\mathrm{B}$. Mixed lineage colonies, derived from HPP-CFCs, containing myeloid and erythroid cells are shown in C and D. Harvest, using a micropipette, of one of the colonies shown in D is shown in $\mathrm{E}$. The small number of cells remaining after the harvest of the colony is shown in F. All colonies were grown in $\mathrm{KL}+\mathrm{FL}+\mathrm{ML}+\mathrm{GM}-\mathrm{CSF}+\mathrm{EPO}+\mathrm{IL}-15$. Colonies were viewed on a $2 \mathrm{~mm}$ grid.

We analyzed 313 colonies grown from $\mathrm{CD}^{-} 8^{-}$progenitors $(\mathrm{n}=$ 5 experiments) and 110 colonies grown from $\mathrm{CD}_{3}{ }^{+}$ progenitors ( $\mathrm{n}=4$ experiments) (22). Progenitors capable of giving rise to myeloid, erythroid and $\mathrm{NK}$ cells were enriched among the $\mathrm{CD}^{-} 8^{-}$fraction, representing $13.7 \%$ of all $\mathrm{CFC}$ compared to $2.7 \%$ among all $\mathrm{CD} 38^{+} \mathrm{CFCs}$. These results are consistent with the belief that stem cells reside among the $\mathrm{CD}^{-} 8^{-}$progenitors, in that multipotent progenitors were enriched among the $\mathrm{CD}^{-} 8^{-}$population. Nonetheless, the majority $(51.8 \%)$ of CD38- CFCs formed colonies containing only myeloid cells. Another $21.7 \%$ had both myeloid and erythroid cells, but no identifiable NK cells. Similarly, pure myeloid (40.0\%) and myeloerythroid (39.1\%) colonies represented the bulk of $\mathrm{CD}^{+} 8^{+}$CFCs. A small (5.5\%) subpopulation of $\mathrm{CD}^{+} 8^{+} \mathrm{CFCs}$ generated erythroid colonies with no identifiable myeloid cells. Such erythroid colonies represented $<1 \%$ of $\mathrm{CD} 38^{-} \mathrm{CFCs}$.

Except for a single colony derived from CD $38^{+} \mathrm{CFCs}$, no pure NK-cell colonies were observed. It should be noted that even this one NK-cell colony contained a number of cells that failed to stain with either the CD14/CD15 or the CD56 mAbs. Not all cells mature in each colony at the same rate. Consequently, our detection methods may fail to ascertain the complete lineage composition of all colonies, especially in small colonies. Analysis of the colonies after 3 weeks of growth represents a compromise between earlier time points at which fewer cells express CD14 or begin to be hemoglobinized and later time points when cells begin to die and the cultures decline $(26,32)$. Presently, we have not had success in expanding the mature NK cells generated in vitro, although the NK cells are functionally mature and capable of killing appropriate target cells (27). In liquid cultures the number of NK cells relative to the numbers of myeloid and erythroid cells is low (generally $<5 \%$ ). Likewise, a mean of only $24.9 \mathrm{CD} 56^{+}$cells were detected/colony (22). This low number of NK cells required the threshold for detection to be set to a low of 3 events above background staining. Nonspecific binding of the FITCconjugated $\operatorname{IgG} 2 \mathrm{~b}$ antibody was very low to non-existent enabling detection of low numbers of $\mathrm{CD}^{2} 6-\mathrm{FITC}^{+}$cells,
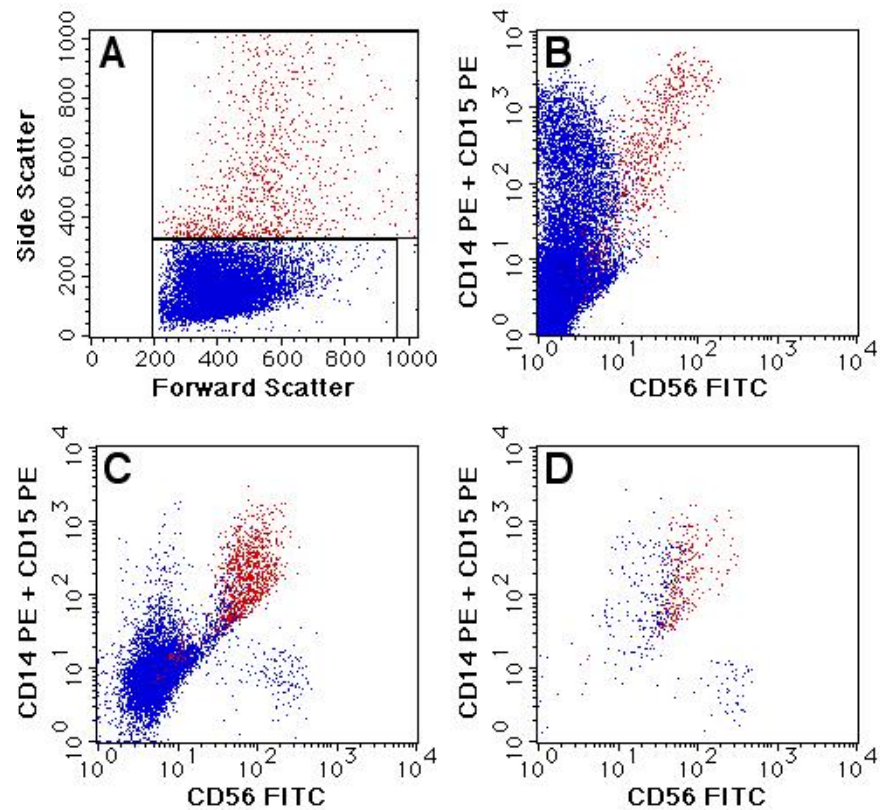

Fig. 3: Determination of lineage content of individual colonies by flow cytometry. Results of three colonies differing in their lineage composition are shown. Low side scatter cells are shown in blue and high side scatter cells are shown in red as indicated in A. A colony containing myelocytes and erythrocytes, but no NK cells, is shown in B. Note the two populations of cells CD14/CD15 cells have distinctive side scatter profiles. A multilineage colony containing erythrocytes, myelocytes, NK cells and most likely $\mathrm{CD}_{14}{ }^{+} \mathrm{DCs}$ is shown in C. A colony containing mostly $\mathrm{CD}_{14} 4^{+} \mathrm{DCs}$ and NK cells is shown in D. All colonies were derived from $\mathrm{CD}^{-} 8^{-}$progenitors $(22)$.

Biological Procedures Online • Vol. 4 No. 1 • June 11, 2002 -www.biologicalprocedures.com 
whereas PE-conjugated mAbs have slightly higher background staining. NK cells were defined as not only CD56 ${ }^{+}$events but also as cells with a low side scatter (Fig. 3), which further reduces the chances of false positives. As culture conditions for the growth of lymphocytes improve we anticipate greater numbers of NK-cell colonies to be detected and the detection of CFCs with B-cell potential to become feasible.

Since a high proliferative capacity is another property of stem cells, we also analyzed the fraction of colonies that grew from HPP-CFCs. HPP-CFCs represented $16.4 \%$ of the CD38- CFCs and $22.0 \%$ of the $\mathrm{CD}_{3}{ }^{+} \mathrm{CFCs}$ (22). Nearly all of these colonies contained both myeloid and erythroid cells. It should be noted that support of the erythroid lineage in our cultures increased the numbers of HPP-CFCs observed over the number observed in the absence of EPO. This is because the presence of erythrocytes in a colony greatly increases the size of the colony. For instance, HPP-CFCs are restricted to the CD34 $4^{++}$ fraction of fetal liver cells when only myelopoiesis is supported (33), whereas further support of erythropoiesis results in colonies with over $1 \times 10^{4}$ cells arising from even the more mature $\mathrm{CD}^{+} 4^{+} \mathrm{Lin}^{-}$population of fetal liver cells (26). When analyzed by flow cytometry, $59.4 \%$ of CD38- HPP-CFC generated colonies containing erythroid, myeloid and NK cells, whereas $46.3 \%$ of $\mathrm{CD} 38^{+}$HPP-CFC generated such colonies (22). Therefore, this analysis further suggested an enrichment of stem cells among the $\mathrm{CD}^{-} 8^{-}$fraction, but the high frequency of multipotent HPP-CFC among $\mathrm{CD}^{+} 8^{+}$progenitors was unexpected. We initially held out the possibility that the presence of multilineage HPP-CFCs among the $\mathrm{CD}_{3} 8^{+}$fraction of progenitors suggests that rare stem cells may also reside among this fraction of fetal liver cells (22). However, recent analysis of the bone marrow reconstituting ability in $\mathrm{NOD} / \mathrm{SCID}$ mice of $\mathrm{CD} 38^{-} \mathrm{CD} 34^{++/+}$and $\mathrm{CD} 38^{+} \mathrm{CD} 34^{++/+}$ progenitors, isolated from umbilical cord blood, showed that long-term reconstituting ability was limited to the CD38fraction (34). We have also subsequently tested the reconstituting potential of the two fractions of fetal liver progenitors and found that only the $\mathrm{CD}^{-} 8^{-}$fraction of progenitors could generate active hematopoiesis in the bone marrow of NOD/SCID mice 8 weeks after transplantation (authors unpublished observations). Thus, it appears that the CD $38^{+}$CFCs with myeloid, erythroid and lymphoid potential represent a population of multipotent progenitors rather than stem cells.

Further analysis of the two subpopulations of CD14/CD15 cells present in the hematopoietic colonies (Fig. 3) indicated that the high side-scatter cells were CD14 ${ }^{+}$DCs (22). These cells were identified as myeloid DCs (DC1) based on their expression of CD2, CD4, CD11a, CD11c, CD40, CD80, CD83, CD86, HLA-DR and HLA-DQ (35-37). Not all high side scatter cells expressed all of these markers, but the general pattern suggested that many of the high side scatter cells represented DCs at varying stages of differentiation. In addition, the marker CD1a was found expressed on most of the DCs generated under our culture conditions, further indicating a myeloid origin for these cells (37).
$\mathrm{CD}^{+} \mathrm{a}^{+}$cells were found in approximately three-quarters of all colonies grown from $\mathrm{CD}_{3} 8^{-}$and $\mathrm{CD}_{3} 8^{+}$progenitors. Examples of CD1a expression on cells isolated from representative colonies are shown in Fig. 4. These colonies were stained with anti-CD56-FITC, anti-CD1a-PE, anti-CD14-APC, anti-CD15APC and PI, enabling us to distinguish non-DC myeloid cells from DCs.
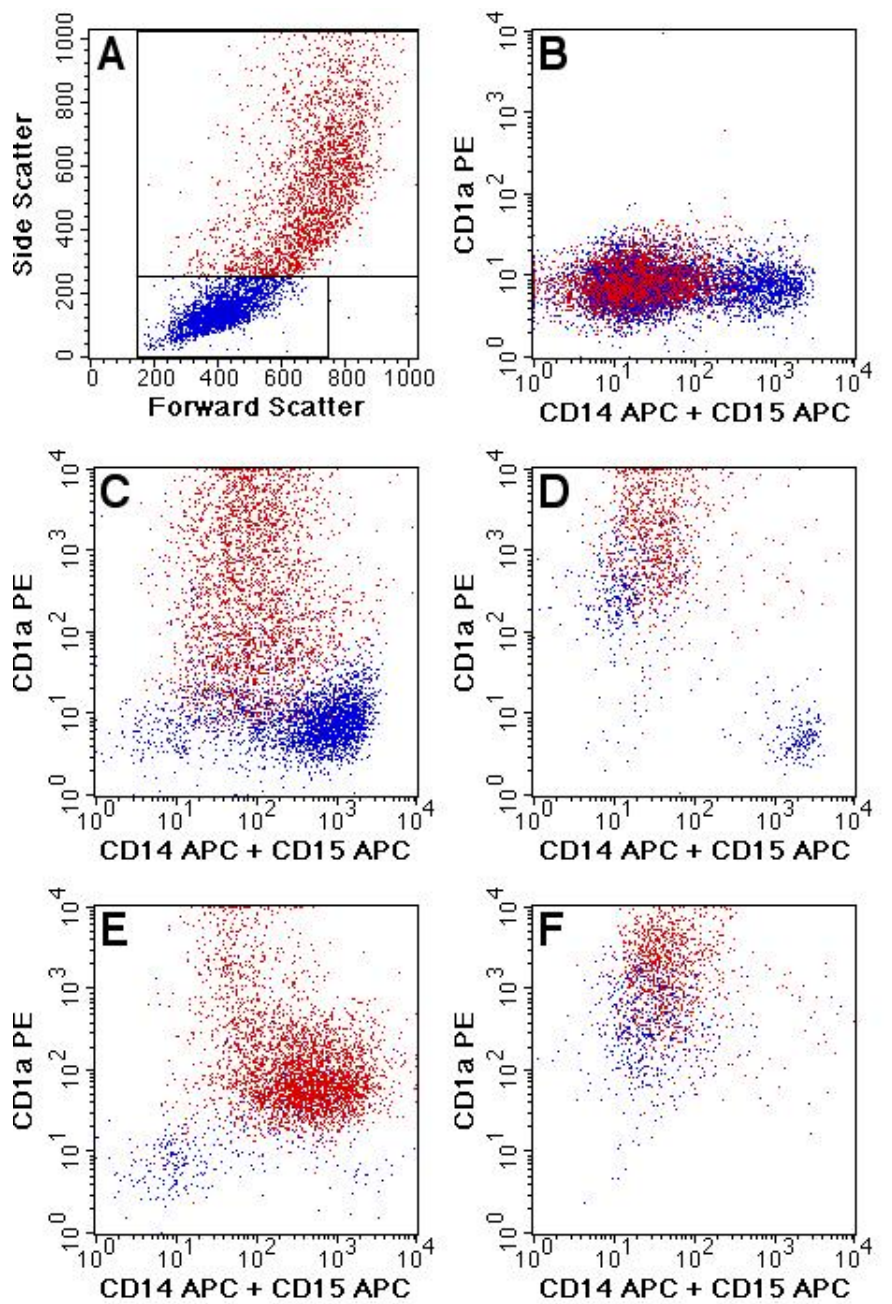

Fig. 4: Flow cytometric analysis of myelocyte and DC content in individual colonies. Results of five colonies differing in their lineage composition are shown. Low side scatter cells are shown in blue and high side scatter cells are shown in red as indicated in A. A colony with myeloid cells but no $\mathrm{CD}^{+}{ }^{+} \mathrm{DCs}$ is shown in B. C-E show colonies with varying frequencies of $\mathrm{CD}^{+} \mathrm{a}^{+}$and $\mathrm{CD} 14 / \mathrm{CD} 15^{+}$cells. $\mathrm{F}$ is an example of a colony primarily composed of CD1a ${ }^{+}$DCs. All colonies shown were derived from $\mathrm{CD} 38^{-}$progenitors.

The stained cells were analyzed on a two-laser FACSCalibur flow cytometer. Colonies containing CD14/CD $15^{+}$myeloid cells, but no DCs, were observed such as shown in Fig. 4B. Varying levels of myeloid and DCs were also observed as exampled by Fig. 4C-E. Note that the expression of CD14 on $\mathrm{CD}^{+} \mathrm{a}^{+}$cells was variable in these colonies (CD15 is not expressed by the high side-scatter cells under these culture conditions). Fig. $4 \mathrm{~F}$ is an example of a colony containing 
primarily DCs and no myeloid cells. Thus, using the techniques described the clonal analysis of CFCs capable of erythroid, myeloid, DC and NK cell differentiation is feasible.

We anticipate that such analyses of the lineage potential of CFCs will be useful in research aimed at understanding the early events of hematopoiesis. Analyses of myeloerythroid progenitors have indicated that hematopoietic differentiation is, in large part, a stochastic process (38). Our analysis of lineage potential of $\mathrm{CD}^{-} 8^{-}$and $\mathrm{CD} 38^{+} \mathrm{CFCs}$ would agree with this assessment. Differentiation, mostly a loss of erythroid potential, was found to occur at the $\mathrm{CD}^{-}$stage of differentiation whereas $\mathrm{CD}_{3} 8^{+}$progenitors still contained many multipotent progenitors. In regards to NK-lymphopoiesis in particular, our data suggests that multiple pathways of differentiation may exist. Recently, Hao et al. demonstrated the existence of a lymphoid committed progenitor among the CD38 fraction (39). Thus, based on our work and that of Galy et al. (31), the data suggest that segregation of the lymphoid from the myeloid and erythroid pathways can occur either very early in hematopoietic differentiation or later at the $\mathrm{CD}_{3} 8^{+}$ stage of differentiation. The possibility also exists for multiple pathways of NK cell differentiation. A lymphoid pathway arising from a common T-, B-, NK- and lymphoid dendriticcell may define one pathway for NK cell differentiation, whereas a myeloid pathway for NK-cell differentiation may also exist $(22,37)$. Such a hypothesis would be consistent with previous observations regarding the stochastic nature of hematopoietic differentiation. Further analysis of the multilineage potential among subsets of early hematopoietic progenitors will help to understand the process of hematopoietic differentiation and the environmental signals that control it.

\section{ACKNOWLEDGEMENTS}

We are indebted to Jane W. Gordon, Sarah R. Elmes, Bill C. Hyun and Paul Dazin for cell sorting and to Drs. Yuet Wai Kan and Michael R. Harrison for their support. This work was supported in part by NIH grant DK59301, a grant from the University of California at San Francisco Academic Senate and a grant from the G. Harold \& Leila Y. Mathers Charitable Foundation.

\section{REFERENCES}

1. Lobach DF, Haynes BF. Ontogeny of the human thymus during fetal development J. Clin. Immunol. 1987;7:81-97.

2. Bárcena A, Galy AHM, Punnonen J, Muench MO, Schols D, Roncarolo MG, de Vries JE, Spits H. Lymphoid and myeloid differentiation of fetal liver CD34+ lineage- cells in human thymic organ culture $J$. Exp. Med. 1994;180:123-132.

3. Crosbie OM, Reynolds M, McEntee G, Traynor O, Hegarty JE, O'Farrelly C. In vitro evidence for the presence of hematopoietic stem cells in the adult human liver Hepatology 1999;29:1193-1198.

4. Humeau L, Namikawa R, Bardin F, Mannoni P, Roncarolo MG, Chabannon C. Ex vivo manipulations alter the reconstitution potential of mobilized human CD34+ peripheral blood progenitors Leukemia 1999;13:438-452.

5. Lemoli RM, Tafuri A, Fortuna A, Catani L, Rondelli D, Ratta M, Tura S. Biological characterization of CD34+ cells mobilized into peripheral blood Bone Marrow Transplant. 1998;22(5):S47-S50.

6. Palis J, Yoder MC. Yolk-sac hematopoiesis: The first blood cells of mouse and man Exp. Hematol. 2001;29:927-936.

7. Medvinsky AL, Dzierzak EA. Development of the definitive hematopoietic hierarchy in the mouse Dev. Comp. Immunol. 1998;22:289-301.

8. Charbord P, Tavian M, Humeau L, Peault B. Early ontogeny of the human marrow from long bones: an immunohistochemical study of hematopoiesis and its microenvironment Blood 1996;87:4109-4119.

9. Bradley TR, Metcalf D. The growth of mouse bone marrow cells in vitro Aust. J. Exp. Biol. Med. Sci. 1966;44:287-300.

10. Ichikawa Y, Pluznik DH, Sachs L. In vitro control of the development of macrophage and granulocyte colonies Proc. Natl. Acad. Sci. USA 1966;56:488-495.

11. Iscove $\mathrm{NN}$, Guilbert LJ, Weyman C. Complete replacement of serum in primary cultures of erythropoietin-dependent red cell precursors (CFU-E) by albumin, transferrin, iron, unsaturated fatty acid, lecithin and cholesterol Exp. Cell Res. 1980;126:121126.

12. Valtieri M, Gabbianelli M, Pelosi E, Bassano E, Petti S, Russo G, Testa U, Peschle C. Erythropoietin alone induces burst formation by human embryonic but not adult BFU-E in unicellular serum-free culture Blood 1989;74:460-470.

13. Bradley TR, Hodgson GS. Detection of primitive macrophage progenitor cells in mouse bone marrow Blood 1979;54:1446-1450.

14. Nakahata T, Ogawa M. Identification in culture of a class of hemopoietic colony-forming units with extensive capability to self-renew and generate multipotential hemopoietic colonies Proc. Natl. Acad. Sci. USA 1982;79:3843-3847.

15. McNiece IK, Langley KE, Zsebo KM. The role of recombinant stem cell factor in early B cell development. Synergistic interaction with IL-7 J. Immunol. 1991;146:3785-3790.

16. Hirayama F, Shih JP, Awgulewitsch A, Warr GW, Clark SC, Ogawa M. Clonal proliferation of murine lymphohemopoietic progenitors in culture Proc. Natl. Acad. Sci. USA 1992;89:5907-5911.

17. Ashany D, Elkon KB, Migliaccio G, Migliaccio AR. Functional characterization of lymphoid cells generated in serum- deprived culture stimulated with stem cell 
factor and interleukin 7 from normal and autoimmune mice J. Cell. Physiol. 1995;164:562-570.

18. Mrozek E, Anderson P, Caligiuri MA. Role of interleukin-15 in the development of human $\mathrm{CD}_{5} 6^{+}$ natural killer cells from CD34+ hematopoietic progenitor cells Blood 1996;87:2632-2640.

19. Ball TC, Hirayama F, Ogawa M. Lymphohematopoietic progenitors of normal mice Blood 1995;85:3086-3092.

20. Aiba Y, Ogawa M. Development of natural killer cells, B lymphocytes, macrophages, and mast cells from single hematopoietic progenitors in culture of murine fetal liver cells Blood 1997;90:3923-3930.

21. Sato T, Laver JH, Aiba Y, Ogawa M. NK cell colony formation from human fetal thymocytes Exp. Hematol. 1999;27:726-733.

22. Muench MO, Bárcena A. Broad distribution of colonyforming cells with erythroid, myeloid, dendritic cell and NK cell potential among $\mathrm{CD} 34^{++}$fetal liver cells $J$. Immunol. 2001;167:4902-4909.

23. Muench MO, Bárcena A, Ohkubo T, Harrison MR. Requirement of retinoids for the expression of CD38 on human hematopoietic progenitors in vitro Cytotherapy 1999; 1:455-467.

24. Xiao M, Dooley DC. Cellular and molecular aspects of human CD34+ CD38- precursors: analysis of a primitive hematopoietic population Leuk. Lymph. 2000;38:489497.

25. Golfier F, Bárcena A, Cruz J, Harrison MR, Muench MO. Mid-trimester fetal livers are a rich source of CD34+/++ cells for transplantation Bone Marrow Transplant. 1999;24:451-461.

26. Muench MO, Namikawa R. Disparate regulation of human fetal erythropoiesis by the microenvironments of the liver and bone marrow Blood Cells Mol. Dis. 2001;27:377-390.

27. Muench MO, Humeau L, Paek B, Ohkubo T, Lanier LL, Albanese CT, Bárcena A. Differential effects of interleukin-3, interleukin-7, interleukin 15, and granulocyte-macrophage colony-stimulating factor in the generation of natural killer and $\mathrm{B}$ cells from primitive human fetal liver progenitors Exp. Hematol. 2000;28:961-973.

28. Ferlazzo G, Klein J, Paliard X, Wei WZ, Galy A. Dendritic cells generated from CD34+ progenitor cells with flt3 ligand, c-kit ligand, GM-CSF, IL-4, and TNFalpha are functional antigen- presenting cells resembling mature monocyte-derived dendritic cells $J$. Immunother. 2000;23:48-58.

29. Curti A, Fogli M, Ratta M, Tura S, Lemoli RM. Stem cell factor and FLT3-ligand are strictly required to sustain the long-term expansion of primitive CD34+DR- dendritic cell precursors J. Immunol. 2001;166:848-854.

30. Bykovskaia SN, Buffo M, Zhang H, Bunker M, Levitt ML, Agha M, Marks S, Evans C, Ellis P, Shurin MR, Shogan J. The generation of human dendritic and NK cells from hemopoietic progenitors induced by interleukin-15 J. Leukoc. Biol. 1999;66:659-666.
31. Galy A, Travis M, Cen D, Chen B. Human T, B, natural killer, and dendritic cells arise from a common bone marrow progenitor cell subset Immunity 1995;3:459473.

32. Muench $\mathrm{MO}$, Roncarolo $\mathrm{MG}$, Menon $\mathrm{S}, \mathrm{Xu} \mathrm{Y}$, Kastelein R, Zurawski S, Hannum CH, Culpepper J, Lee F, Namikawa R. FLK-2/FLT-3 ligand (FL) regulates the growth of early myeloid progenitors isolated from human fetal liver Blood 1995;85:963-972.

33. Muench MO, Cupp J, Polakoff J, Roncarolo MG. Expression of CD33, CD38 and HLA-DR on CD34+ human fetal liver progenitors with a high proliferative potential Blood 1994;83:3170-3181.

34. Hogan CJ, Shpall EJ, Keller G. Differential long-term and multilineage engraftment potential from subfractions of human CD34+ cord blood cells transplanted into NOD/SCID mice Proc. Natl. Acad. Sci. USA 2002;99:413-418.

35. Zhou LJ, Tedder TF. CD14 ${ }^{+}$blood monocytes can differentiate into functionally mature CD83+ dendritic cells Proc. Natl. Acad. Sci. USA 1996;93:2588-2592.

36. Spits H, Couwenberg F, Bakker AQ, Weijer K, Uittenbogaart $\mathrm{CH}$. Id 2 and Id 3 inhibit development of CD34(+) stem cells into predendritic cell (pre-DC)2 but not into pre-DC1. Evidence for a lymphoid origin of pre-DC2 J. Exp. Med. 2000;192:1775-1784.

37. de Yebenes VG, Carrasco YR, Ramiro AR, Toribio ML. Identification of a myeloid intrathymic pathway of dendritic cell development marked by expression of the granulocyte macrophage-colony- stimulating factor receptor Blood 2002;99:2948-2956.

38. Ogawa M. Stochastic model revisited Int. J. Hematol. 1999;69:2-5.

39. Hao QL, Zhu J, Price MA, Payne KJ, Barsky LW, Crooks GM. Identification of a novel, human multilymphoid progenitor in cord blood Blood 2001;97:3683-3690.

40. Rice HE, Hedrick MH, Flake AW, Donegan E, Harrison MR. Bacterial and fungal contamination of human fetal liver collected transvaginally for hematopoietic stem cell transplantation Fetal Diagn. Ther. 1993;8:74-78.

41. Hern WM. Correlation of fetal age and measurements between 10 and 26 weeks of gestation Obstet. Gynecol. 1984;63:26-32.

42. Mercer BM, Sklar S, Shariatmadar A, Gillieson MS, D'Alton ME. Fetal foot length as a predictor of gestational age Am. J. Obstet. Gynecol. 1987;156:350355.

43. Merz E, Oberstein A, Wellek S. Age-related reference ranges for fetal foot length Ultraschall. Med. 2000;21:79-85.

44. Mychaliska GB, Muench MO, Rice HE, Leavitt AD, Cruz J, Harrison MR. The biology and ethics of banking fetal liver hematopoietic stem cells for in utero transplantation. J. Pediatr. Surg. 1998;33:394-399. 


\section{PROTOCOLS}

\section{Protocol 1: Isolation of defined subsets of progenitors from human fetal liver}

\section{Reagents:}

Cell Wash Buffer (PBS/BSA). The standard medium used to wash and hold cells in suspension during the isolation procedure consists of phosphate buffered saline (PBS), without $\mathrm{Ca}^{2+}$ and $\mathrm{Mg}^{2+}$, containing $0.3 \%$ bovine serum albumin (BSA) (product \#100362; Roche Molecular Biochemicals, Indianapolis, IN, http://www.ibuyrmb.com) and 50 $\mu \mathrm{g} / \mathrm{mL}$ gentamicin sulfate (\# 15750, Life Technologies/Gibco BRL, http://www.lifetech.com). PBS/BSA is prepared by dissolving 3g BSA in 1L PBS and adding $1 \mathrm{~mL}$ of $50 \mathrm{mg} / \mathrm{mL}$ gentamicin sulfate. The solution is sterilized by filtration $(0.22 \mu)$ and stored at $4^{\circ} \mathrm{C}$. PBS containing $2 \%$ fetal bovine serum (FBS) can be used in place of PBS/BSA if the cells are not to be grown under defined culture conditions.

Blocking Buffer. PBS is supplemented with $0.01 \% \mathrm{NaN}_{3}$ (Sigma Chemical Company; St. Louis, MO, http://www.sigmaaldrich.com) and 5\% normal mouse serum (Gemini Bio-Products, Woodland, CA, http://www.gembio.com). The solution is filtered $(0.22 \mu)$ to remove precipitates from the serum. Store at $4^{\circ} \mathrm{C}$.

FACS Wash Buffer. This buffer is made by adding $\mathrm{NaN}_{3}$ at a final concentration of $0.01 \%$ to PBS/BSA. Store at $4^{\circ} \mathrm{C}$.

FACS PI Buffer. This buffer is prepared by adding $\mathrm{NaN}_{3}$ to a final concentration of $0.01 \%$ and propidium iodide (Molecular Probes, Eugene, OR, http://www.probes.com) to a final concentration of $2 \mu \mathrm{g} / \mathrm{ml}$ to PBS/BSA. Store at $4{ }^{\circ} \mathrm{C}$.

Cell-dissociation cup. (Sigma Chemical Company, \#CD-1) Use with a 50 or 60 mesh screen and glass pestle.

Disposable plasticware: $35 \times 10 \mathrm{~mm}$ tissue culture dish (Falcon, BD Bioscience), $100 \times 20 \mathrm{~mm}$ tissue culture dish (Falcon), 50ml conical tubes (Falcon), T25 flask, $15 \mathrm{~mL}$ polypropylene tube, $15 \mathrm{~mL}$ polystyrene tubes, $12 \times 75 \mathrm{~mm}$ tubes (Falcon brand tubes are highly recommended for flow cytometers manufactured by Becton Dickinson), 1.2mL microtiter tubes (\#02-681-376, Fisher Scientific, Pittsburgh, PA, http://www.fishersci.com).

0.4\% Trypan blue. (\#15250-061, Life Technologies)

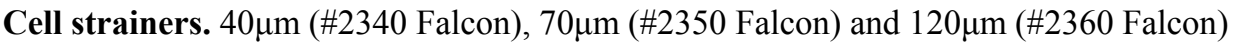

1.077g/mL Nycoprep. (\#100-2368, Life Technologies)

BioMag goat anti-mouse IgG magnetic particles. (\#84340, Polysciences, Inc., Warrington, PA, http://www.polysciences.com). Wash the beads twice before use using PBS/BSA as recommended by the manufacturer. Suspend the washed beads in $10-20 \mathrm{~mL}$ $\mathrm{PBS} / \mathrm{BSA}$.

Sheep anti-mouse coated Dynabeads. (\#110.02, Dynal Biotech Inc., Lake Success, NY, http://www.dynal.no) 
Monoclonal antibodies (mAb):

\begin{tabular}{|c|c|c|c|c|}
\hline Specificity-Label & Clone & Product \# & Isotype & Source \\
\hline CD3-FITC $^{1}$ & SK7 & 349201 & $\operatorname{lgG} 1$ & BD Biosciences, http://www.bdbiosciences.com \\
\hline CD14-FITC ${ }^{1}$ & TüK4 & MHCD1401 & $\lg G 2 a$ & Caltag Laboratories, http://www.caltag.com \\
\hline CD19-FITC & SJ25C1 & 340409 & $\operatorname{lgG} 1$ & BD Biosciences \\
\hline CD20-FITC & $\mathrm{HI} 47$ & MHCD2001 & $\operatorname{lgG} 3$ & Caltag Laboratories \\
\hline CD34-FITC & 581 & IM 1870 & $\operatorname{lgG} 1$ & $\begin{array}{l}\text { Beckman-Coulter, } \\
\text { http://www.beckmancoulter.com }\end{array}$ \\
\hline CD34-APC ${ }^{1}$ & 581 & IM2472 & $\lg G 1$ & Beckman-Coulter \\
\hline CD38-PE & HB7 & 347687 & $\lg G 1$ & BD Biosciences \\
\hline CD56-FITC & C5.9 & 0562 & $\lg G 2 b$ & Exalpha Inc., http://www.exalpha.com \\
\hline CD235a & 10F7MN & HB-8162 & $\lg G 1$ & ATCC $^{1}$, http://www.atcc.org \\
\hline CD235a-FITC & 11E4B-7-6 & IM2212 & $\operatorname{lgG} 1$ & Beckman-Coulter Inc \\
\hline None/FITC & polyclonal & MG101 & $\lg G 1$ & Caltag Laboratories \\
\hline None/PE & polyclonal & MG104 & $\lg G 1$ & Caltag Laboratories \\
\hline None/APC & polyclonal & IM 2475 & $\lg G 1$ & Beckman-Coulter Inc. \\
\hline
\end{tabular}

\section{Protocol:}

1. Fetal liver, obtained from elective abortion performed by cervical dilatation and extraction, is usually disrupted and contaminated with microbes (40). Large pieces of liver tissue can most often be obtained, but they are rarely intact or sterile. The gestational age of the abortuses is approximated from the foot-length of the fetus using standard nomograms (41-43). The liver is transported to the laboratory in $50 \mathrm{~mL}$ tubes in approximately $30 \mathrm{~mL}$ PBS/BSA at $4^{\circ} \mathrm{C}$. Alternatively, the single antibiotic in the PBS/BSA solution can be substituted for a more potent combination of anti-microbial drugs consisting of erythromycin lactobionate $(100 \mu \mathrm{g} / \mathrm{mL})$, gentamicin sulfate $(50 \mu \mathrm{g} / \mathrm{mL})$, vancomycin hydrochloride $(100 \mu \mathrm{g} / \mathrm{mL})$, and amphotericin B $(2.5 \mu \mathrm{g} / \mathrm{mL})(25)$. Although unprocessed liver is most often contaminated, after processing and cell sorting very few tissues show any evidence of microbial contamination (44). The liver is transported on ice and, in our laboratory, processing begins within 6 hours after abortion.

2. Wash the liver twice with $20 \mathrm{~mL}$ of PBS/BSA and place the tissue in about $20 \mathrm{~mL}$ of PBS/BSA into a cell-dissociation cup resting on the bottom half of a $100 \times 20 \mathrm{~mm}$ petri dish. Press the liver through the screen using a glass pestle. In the beginning, use vertical motions with the pestle as much as possible to avoid killing cells by shearing them across the mesh. The cell suspension can be recycled through the mesh to help wash cells through. Collect the cell suspension and place it in a new $50 \mathrm{~mL}$ tube. Press the remaining fragments of liver through the mesh and wash with small volumes (7$10 \mathrm{ml}$ ) of PBS/BSA. Most specimens can be prepared in a final volume of $50 \mathrm{ml}$ ( 1 tube), unless the liver is particularly large in which case 2 tubes can be used. The dissociation of the liver is finished when the majority of the red pulp has been recovered leaving behind a white-colored tissue (biliary tree, ligament, etc). The number of viable cells is determined using trypan blue exclusion and a hemocytometer. All live cells, including erythrocytes, are counted to quantify the amount of $\mathrm{mAb}$ required for depletion of the red cells. In our experience, livers between the gestational ages of 16 and 24 weeks contain a median $2 \times 10^{9}$ cells (range $3.9 \times 10^{8}$ to $\left.1.1 \times 10^{10}\right)(25)$. 
3. Label the fetal erythrocytes using anti-CD235a mAb by incubating the cells with a saturating amount of mAb in the form of culture supernatant from the $10 \mathrm{~F} 7 \mathrm{MN}$ cell line. Culture supernatant is used to reduce the cost of the procedure, but commercially available unconjugated or FITC-labeled anti-CD235a mAb can be substituted. Incubate for 30 minutes on ice. (The BioMag beads can be washed during this time, see step 5 below.)

4. Pellet the cells by centrifugation ( 7 minutes at $300 \mathrm{X} g$ at $4{ }^{\circ} \mathrm{C}$ ), remove the cloudy supernatant and suspend the cells in $50 \mathrm{~mL}$ PBS/BSA. Wash the cells by centrifugation again and suspend the washed cells in $20 \mathrm{~mL}$ of PBS/BSA. If a large number of cell clumps have developed, the cells can be filtered using $120 \mu \mathrm{m}$ (or smaller) cell strainer. The liberal use of cell strainers to remove clumps of cells is recommended throughout the isolation procedure. Hepatocytes and other cell types are destroyed by the repeated centrifugation of the cells, leading to clumping of the dead and live cells.

5. The labeled $\mathrm{CD} 235 \mathrm{a}^{+}$cells are depleted using a 5:1 ratio of BioMag magnetic particles per cell. We have reduced the number of particles recommended by the manufacturer to achieve a good level of depletion at a low cost. Add the liver cell suspension to the washed beads in a $25 \mathrm{~cm}^{2}$ tissue culture flask. Mix and incubate on ice for 15 minutes. Mix the flask several times during the incubation period. Place the flask against a magnet and allow the beads to be attracted towards the magnet for at least 5 minutes. Remove the unbound liver cells and place into a $50 \mathrm{~mL}$ tube. Without removing the flask from the magnet, gently add $10-20 \mathrm{~mL}$ of PBS/BSA to help rinse out the remaining unbound cells. Add the rinse volume of PBS/BSA to the cells in the $50 \mathrm{~mL}$ tube. The erythrocyte depletion is likely to be incomplete and the recovered cell suspension may still appear dark red/brown in color. Most of the contaminating erythrocytes and magnetic beads are depleted in the next step of the protocol.

6. Pellet the cells by centrifugation ( 7 minutes at $300 \mathrm{X} g$ at $4{ }^{\circ} \mathrm{C}$ ). Suspend the pellet in $5 \mathrm{~mL}$ of PBS/BSA. Filter using a 70 or $40 \mu$ mesh cell strainer if necessary. Slowly layer the cell suspension on top of $7 \mathrm{~mL}$ of Nycoprep density medium in a $15 \mathrm{~mL}$ polypropylene tube. Centrifuge for 25 minutes at $800 \mathrm{X} g$ at room temperature $\left(20-25^{\circ} \mathrm{C}\right)$ with the brake off. Collect the light density fraction and add these light density fetal liver (LDFL) cells to a $15 \mathrm{~mL}$ tube. Discard the pelleted cells. Fill the tube containing the LDFL with PBS/BSA, mix and centrifuge ( 7 minutes at $300 \mathrm{X} g$ at $4^{\circ} \mathrm{C}$ ). Remove the supernatant down to $0.1 \mathrm{~mL}$ and add $0.9 \mathrm{~mL}$ of blocking buffer. Count the number of live cells recovered (viability at this stage should by high). Typically, $2-4 \times 10^{7}$ cells are recovered per tissue, but recovery may be higher if many immature erythrocytes have escaped the depletion procedure. Place the cells on ice for several minutes. It is important to save an aliquot of these cells for use as controls for setting up the flow cytometer (see step 11 below).

7. Add saturating amounts of FITC-labeled mAbs for the depletion of mature blood cells and committed B-cell progenitors, collectively called lineage ${ }^{+}\left(\mathrm{Lin}^{+}\right)$cells:

\begin{tabular}{lll}
\hline Table 2: & \\
\hline Mab Specificity & Cell Specificity & Volume \\
CD3 & T cells & $20 \mu \mathrm{L}$ \\
CD14 & Monocytes & $10 \mu \mathrm{L}$ \\
CD19 & B cells and B-cell progenitors & $40 \mu \mathrm{L}$ \\
CD20 & B cells and B-cell progenitors & $20 \mu \mathrm{L}$ \\
CD56 & NK cells and T cells & $20 \mu \mathrm{L}$ \\
CD235a & Erythrocytes & $20 \mu \mathrm{L}$ \\
\hline
\end{tabular}

8. Incubate on ice for 30 minutes or overnight (if cell sorting is to be performed the next day).

9. Wash the cells twice with PBS/BSA (7 minutes at $300 \mathrm{X} g$ at $4^{\circ} \mathrm{C}$ ). Suspend the cells in $2 \mathrm{~mL}$ of $\mathrm{PBS} / \mathrm{BSA}$ and mix with Dynabeads at a ratio of 5 beads per cell in a $15 \mathrm{~mL}$ polystyrene tube. Incubate for 15 minutes with constant mixing at $4{ }^{\circ} \mathrm{C}$. Add PBS/BSA to a volume of $12 \mathrm{~mL}$. Place the tube next to a magnet and allow the particles to collect to the wall of the tube for 2 minutes. Recover the unbound cells to a new $15 \mathrm{~mL}$ tube and subject them to a second round of magnetic depletion. Recover the unbound cells and concentrate by centrifugation ( 7 minutes at $300 \mathrm{X} g$ at $4^{\circ} \mathrm{C}$ ). The pellet should 
contain very few, if any, visible erythrocytes. Suspend the cells in $1 \mathrm{~mL}$ of blocking buffer, and determine the number of live cells recovered. Typically, 1-2 x $10^{7}$ Lin-LDFL cells are recovered per tissue.

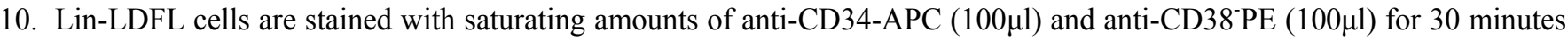
on ice or overnight at $4^{\circ} \mathrm{C}$.

11. The cells are washed twice by centrifugation in PBS/BSA for 7 minutes at $300 \mathrm{X} g$ at $4{ }^{\circ} \mathrm{C}$. The washed cells are suspended in $3-4 \mathrm{~mL}$ FACS PI Buffer and filtered through a $40 \mu \mathrm{m}$ cell strainer into a $12 \times 75 \mathrm{~mm}$ tube. The cells are kept in the dark at $4^{\circ} \mathrm{C}$ until cell sorting.

12. Controls for setting up the flow cytometer can be prepared using an aliquot of CD235a LDFL cells saved for this purpose. Use about $2 \times 10^{5}$ cells per staining. On overview of the controls needed, as well as the sort itself, are shown in the table below. Samples \#1 and \#5 are not strictly necessary, but are nonetheless useful. Cells for sample \#1 can be added directly to $0.5 \mathrm{~mL}$ of FACS PI buffer in a $12 \times 75 \mathrm{~mm}$ tube and held at $4^{\circ} \mathrm{C}$ until needed. Add the cells for samples \#2-5 in a volume of $10-50 \mu \mathrm{l}$ blocking buffer into 96 -well V-bottom plates. Incubate the cells together with the indicated volume of

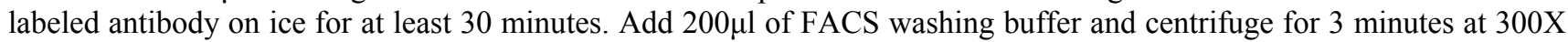
$g$ at $4^{\circ} \mathrm{C}$. Discard the supernatant by quickly inverting the plate, leaving the pelleted cells behind in the plate. Repeat the washing procedure with $250 \mu \mathrm{l}$ of FACS washing buffer, suspending the pelleted cells with the addition of the washing buffer. Suspend the washed samples in $0.5 \mathrm{~mL}$ of FACS PI Buffer. Dispense the cells into $1.2 \mathrm{~mL}$ microtiter for analysis. These microtiter can be placed inside the larger $12 \times 75 \mathrm{~mm}$ tubes, which fit the sample ports of flow cytometers.

\begin{tabular}{lllll}
\hline Table 3: & & & & \\
\hline Sample & FITC & PE & APC & PI \\
\#1 Unstained & none & none & none & yes \\
\#2 Isotype Control & $\operatorname{lgG}(5 \mu \mathrm{l})$ & $\operatorname{lgG} 1(5 \mu \mathrm{l})$ & $\operatorname{lgG}(10 \mu \mathrm{l})$ & yes \\
\#3 FITC Compensation & CD34 $(20 \mu \mathrm{l})$ & $\operatorname{lgG} 1(5 \mu \mathrm{l})$ & $\operatorname{lgG} 1(10 \mu \mathrm{l})$ & yes \\
\#4 PE Compensation & $\operatorname{lgG} 1(5 \mu \mathrm{l})$ & $\mathrm{CD} 38(10 \mu \mathrm{l})$ & $\operatorname{lgG} 1(10 \mu \mathrm{l})$ & yes \\
\#5 APC Compensation & $\operatorname{lgG} 1(5 \mu \mathrm{l})$ & $\operatorname{lgG} 1(5 \mu \mathrm{l})$ & $\mathrm{CD} 34(10 \mu \mathrm{l})$ & yes \\
\#6 The Sort & Lin panel & $\mathrm{CD} 38$ & $\mathrm{CD} 34$ & yes \\
\hline
\end{tabular}

13. Cells are sorted as shown in Fig. 1. Live cells are selected based on the lack of PI staining (region 1). Region 2 is set to include cells with a low to moderate forward light scatter and low side light scatter profile. This gate can be adjusted by gating on $\mathrm{CD}_{3} 4^{++}$cells and examining the forward and side light-scatter properties of these cells. Any remaining Lin ${ }^{+}$ cells are removed using region 3 to select Lin-FITC cells. The expression of CD34 and CD38 is viewed on cells found in all three regions. Regions are drawn to isolate the desired subpopulations of progenitors. Sample \#5 of the controls is useful in defining lack of CD38 expression on $\mathrm{CD} 34^{++}$cells. We define $\mathrm{CD} 34^{++}$as the level of CD34 expression found on CD $38^{-}$cells that express high levels of CD34. When isolating both $\mathrm{CD} 38^{-} \mathrm{CD} 34^{++} \mathrm{Lin}^{-}$and $\mathrm{CD} 38^{+} \mathrm{CD} 34^{++} \mathrm{Lin}^{-}$cells, the goal is to obtain cells with the same level of CD34 expression. Regions need to be drawn conservatively as reanalysis of the sorted cells invariable indicates a spread in the sorted cells from their original regions.

\section{Protocol 2: Culture of colony-forming cells with erythroid, myeloid and lymphoid potential.}

\section{Reagents:}

\section{X serum-deprived medium:}

1. Dissolve a $1 \mathrm{~L}$ package of powdered Iscove's modified Dulbecco's medium (IMDM \#12200, Life Technologies) in about $800 \mathrm{~mL}$ of tissue culture grade (deionized) water.

2. Stir in 3.024g of sodium bicarbonate (\#S-4019, Sigma Chemical Company) 
3. Add 40g of fraction-V ethanol-extracted BSA (\#100 362, Boehringer Mannheim Biochemicals, http://www.boehringermannheim.com) to the surface of the medium and let the BSA dissolve without stirring. This step will take about 1-2 hours.

4. Add 400mg of human iron-saturated (holo) transferrin (\#82-349-1, Serologicals Proteins Inc., Kankakee, IL).

5. Add 20mg of recombinant human insulin (\#1376 497, Boehringer Mannheim Biochemicals). Stock aliquots of 10mg/ml are stored at $-80^{\circ} \mathrm{C}$.

6. Add $650 \mu \mathrm{l}$ of a $1 \%$ solution of $\alpha$-thioglycerol (\#M-6145, Sigma Chemical Company). Use freshly prepared $1 \%$ $\alpha$-thioglycerol made by adding $100 \mu \mathrm{l}$ to $9.9 \mathrm{~mL}$ of water or PBS.

7. Add deionized water to $1 \mathrm{~L}$.

8. Sterile filter and store at $4^{\circ} \mathrm{C}$ or freeze at aliquots at $-20^{\circ} \mathrm{C}$ for long-term storage.

\section{$2.4 \%(2 X)$ methylcellulose:}

1. 1) Sterilize $500 \mathrm{~mL}$ of tissue culture grade water in a large (2L) flask with a large magnetic stir bar inside the flask.

2. Sterilize $24 \mathrm{~g}$ of 4000 centipoises methylcellulose (\#M0512, Sigma Chemical Company) in a 500mL beaker.

3. Carefully remove the flask containing the water from the autoclave while still hot. Transfer the flask to a heated stir plate that is set up inside a laminar flow hood. Bring the water to a boil and slowly add the methylcellulose powder. Exercise caution as addition of the methylcellulose will cause the boiling water to foam and possibly spill out of the flask. Addition of the methylcellulose may take 15 to 30 minutes.

4. Turn off the heater and allow the methylcellulose suspension to stir and cool to $=37^{\circ} \mathrm{C}$. This may take a over an hour.

5. Prepare $500 \mathrm{~mL} 2 \mathrm{X}$ IMDM by dissolving a $1 \mathrm{~L}$ package of IMDM and adding $3.024 \mathrm{~g}$ sodium bicarbonate and $650 \mu \mathrm{l}$ of a $1 \%$ solution of a-thioglycerol, prepared as described above.

6. Once the methylcellulose solution has cooled sufficiently, add the 2X IMDM. Make sure the flask is well covered with foil to keep the contents sterile and transfer the flask to a stir plate at $4{ }^{\circ} \mathrm{C}$. Stir vigorously overnight. At some point during the mixing process the methylcellulose will dissolve and the increased viscosity of the solution will prevent further stirring.

7. Aliquot the $2 \mathrm{X}$ methylcellulose solution by pouring approximately $40 \mathrm{~mL}$ into $50 \mathrm{~mL}$ polypropylene tubes. Aliquots can be kept frozen for at least a year at $-20^{\circ} \mathrm{C}$.

Cytokines. Cytokines are available from R\&D Systems, Inc. (Minneapolis, MN, http://www.rndsystems.com) or from PeproTech Inc. (Rocky Hill, NJ, http://www.peprotech.com). Cytokines are diluted in IMDM with 2\% BSA and 50 $\mu \mathrm{g} / \mathrm{ml}$ gentamicin at 100X final concentration and stored in $1 \mathrm{~mL}$ aliquots at $-80^{\circ} \mathrm{C}$.

\begin{tabular}{lll}
\hline Table 4: & & \\
\hline Cytokine & Concentration used & Product \#/Source \\
EPO & $10 U n i t s / m l$ & $287-T C / R \& D$ Systems \\
FL & $100 \mathrm{ng} / \mathrm{ml}$ & $300-19$ / PeproTech \\
GM-CSF & $20 \mathrm{ng} / \mathrm{ml}$ & $215-\mathrm{GM} /$ R\&D Systems \\
IL-15 & $20 \mathrm{ng} / \mathrm{ml}$ & $247-I L / R \& D$ Systems \\
SCF & $50 \mathrm{ng} / \mathrm{ml}$ & $255-S C$ / R\&D Systems \\
TPO & $20 \mathrm{ng} / \mathrm{ml}$ & $288-T P / R \& D$ Systems \\
\hline
\end{tabular}


Human low density lipoprotein (LDL). (\#L-2139, Sigma Chemical Company).

Gentamicin sulfate (50mg/mL). (Life Technologies)

\section{Protocol:}

1. Suspend cells in $2 X$ serum-deprived medium. Cells should be plated a low cell concentration (e.g. 50 cells/plate for fetal progenitors) such that fewer than 20 colonies develop/dish. Preliminary experiments to determine the optimal cell number for plating may be required when the concentration of CFCs is not known.

2. The final concentrations of all the components are as follows: $1 \mathrm{X}$ serum-deprived medium, $1.2 \%$ methylcellulose, $50 \mu \mathrm{g} / \mathrm{mL}$ gentamicin, $20 \mu \mathrm{g}$-protein $/ \mathrm{mL}$ LDL, cytokines (concentrations as listed above) and the appropriate cell concentration. The components are mixed in the following order in $50 \mathrm{~mL}$ tube: $2 \mathrm{X}$ serum-deprived medium (final volume less the other components), cells (volume variable with concentration), cytokines $(10 \mu \mathrm{L} / \mathrm{mL})$, gentamicin $(1 \mu \mathrm{L} / \mathrm{mL}), \mathrm{LDL}$ (volume variable with product lot) and then $2 \mathrm{X}$ methylcellulose (half final volume). Mix the liquid components well before adding the $2 \mathrm{X}$ methylcellulose. Measure and dispense the $2 \mathrm{X}$ methylcellulose using a syringe without a needle. Vigorously mix the final solution. Let stand for a few minutes to allow air-bubbles to rise.

3. Dispense $1 \mathrm{~mL}$ of the final solution into the tissue culture dishes using a syringe with a 16 gauge needle. Disperse the medium by tipping the plates back and forth. Place the plates into a larger petri dish or a sealed chamber with a dish full of sterile water.

4. Culture at $37^{\circ} \mathrm{C}$ in a fully humidified atmosphere consisting of $5 \% \mathrm{CO}_{2}$ in air for 3 weeks. Mature progenitors, expressing low levels of $\mathrm{CD} 34$, may require less time in culture to mature.

\section{Protocol 3: Detection of CFCs with erythroid, myeloid and lymphoid potential.}

\section{Reagents:}

Blocking Buffer. (see protocol 1)

FACS washing buffer. (see protocol 1)

FACS PI buffer. (see protocol 1)

mAbs:

\begin{tabular}{lllll}
\hline Table 5: & & & & \\
\hline Specificity-Label & Clone & Product \# & Isotype & Source \\
CD1a-PE & T6 & $\mathrm{IM} 1942$ & $\operatorname{lgG}$ & Beckman-Coulter Inc. \\
CD14-APC & $\mathrm{M} 5 \mathrm{E} 2$ & 555399 & $\operatorname{lgG} 2 \mathrm{a}$ & BD Biosciences \\
CD15-APC & $\mathrm{HI98}$ & 551376 & $\operatorname{lgM}$ & BD Biosciences \\
CD56-FITC & $\mathrm{C5.9}$ & 0562 & $\operatorname{lgG}_{2 \mathrm{~b}}$ & Exalpha Inc., Boston, MA \\
\hline
\end{tabular}

Disposable plasticware: 60 x $15 \mathrm{~mm}$ culture dish with a $2 \mathrm{~mm}$ grid (\#25011 Corning Inc., Corning, NY, http://www.scienceproducts.corning.com), non-sterile 96-well V-bottom plate (Costar Serocluster 96 \#3897, Corning Inc.), 1.2mL microtiter tubes.

\section{Protocol:}

1. Prepare a solution of $10 \mathrm{~mL}$ blocking buffer containing $250 \mu \mathrm{l}$ anti-CD1a-PE, $250 \mu \mathrm{l}$ anti-CD14-APC, $250 \mu 1$ anti-CD15APC and $250 \mu \mathrm{L}$ anti-CD56-FITC mAbs. Dispense $100 \mu \mathrm{L} /$ well of a $96-$ well plate (more or less may be used depending on the number of colonies to be analyzed). Staining with these markers will be used to determine the presence of dendritic 
$\left(\mathrm{CD} 1 \mathrm{a}^{+} \mathrm{CD} 14^{+/}\right)$myeloid $\left(\mathrm{CD} 14^{+}\right.$and/or $\mathrm{CD} 15^{+}$cells) and $\mathrm{NK}$ cells $\left(\mathrm{CD} 56^{+}\right.$cells) within the individual colonies. The plate is kept on ice in an ice bucket for easy access while scoring the culture dishes.

2. Colonies are scored with the aid of a dissecting microscope. Placement of the culture dishes on an inverted culture dish with a $2 \mathrm{~mm}$ grid is useful in scoring the cultures and estimating the size of the colonies. A written log is kept of the visibly observed properties of the colonies such as size and the presence of erythrocytes. Erythrocytes are identified visually by the presence of hemoglobinized cells. Alternatively, erythrocytes can be identified by flow cytometry after staining with labeled CD235a mAb. However, the number of parameters that can be measured flow cytometrically is limited and erythrocytes are easily identified visually. Individual colonies are plucked using a $200 \mu \mathrm{L}$ pipette. This is best accomplished by loading a clean pipette tip with about $20 \mu \mathrm{L}$ of the blocking buffer/mAb solution, with the pipette set for $150 \mu \mathrm{L}$, and then harvesting the colony from the semi-solid medium. The colony is harvested while under visual inspection using the microscope. Care is taken to harvest as much of the colony as possible without acquiring cells from a nearby colony. The cells are dispersed in the blocking buffer/mAb solution remaining in the well. The preloaded solution helps to push the cells and methylcellulose out of the pipette tip, but repeated pipetting is recommended to completely flush the pipette tip. The position of individual colonies in the 96-well plate is recorded to later correlate the visual and flow cytometric observations. After the last colony has been harvested, the cells are left to stain at $4^{\circ} \mathrm{C}$ for at least 30 minutes in the dark.

3. The stained cells are washed once by adding $150 \mu \mathrm{L}$ of FACS washing buffer and centrifuged for 3 minutes at $300 \mathrm{X} g$ at $4^{\circ} \mathrm{C}$. Discard the supernatant by quickly inverting the plate, leaving the pelleted cells behind in the plate. Suspend the samples in $100 \mu \mathrm{L}$ of FACS PI Buffer. Dispense the cells into $1.2 \mathrm{~mL}$ microtiter tubes in a rack with a 96 -well format for analysis. Use of a multichannel pipette and maintaining the 96-well format throughout the staining procedure facilitates handling of a large number of samples. The microtiter tubes can be, in turn, placed inside a larger $12 \mathrm{x} 75 \mathrm{~mm}$ tube, required by flow cytometers, immediately before analysis.

4. Controls required to adjust the parameters of the flow cytometer can be obtained from either a small sample of cells grown in liquid culture in parallel with the clonal cultures and/or from colonies grown in a spare culture dish. $1 \mathrm{x} 10^{3}$ cells grown in $10 \mathrm{~mL}$ of medium and cytokines will provide plenty of cells for all controls after 3 weeks of growth. Background staining is determined by staining with the nonspecific labeled antibodies listed above. Compensation is performed with cells stained individually with the FITC-, PE- and APC-labeled mAbs. Note that the frequency of NK cells generated is low and use of another marker such as CD235a-FITC may make adjusting compensation for the FL-1 parameter easier. There are minor differences in the size and autofluorescence of cells grown in liquid culture and cells grown in semi-solid cultures. For this reason, we routinely stain one large multilineage (erythroid-myeloid) colony with the non-specific labeled antibodies as a control for determining the placement of regions in the analysis of the flow cytometric data.

5. Data is collected based on time rather than event count such that a similar proportion of small and large colonies is analyzed. Our flow cytometers are set to collect 60 seconds of data, which requires nearly the whole of the $100 \mu \mathrm{L}$ sample. We define the presence of a population based on the finding of at least 3 events above background. 